\title{
EDUCAÇÃO ESCOLAR QUILOMBOLA: REFLEXÕES SOBRE OS AVANÇOS DAS POLÍTICAS EDUCACIONAIS E OS DESAFIOS PARA A PRÁTICA PEDAGÓGICA NO VALE DO RIBEIRA-SP
}

\author{
Lisângela Kati do Nascimento (USP)*
}

\begin{abstract}
RESUMO
Esse texto tem por objetivo tematizar os avanços nas políticas educacionais para a população quilombola, focando mais especificamente nas Diretrizes Curriculares Nacionais para a Educação Escolar Quilombola, e problematizar alguns dos principais desafios e obstáculos a serem enfrentados no processo de efetivação da modalidade de educação escolar quilombola na educação básica. A análise aqui empreendida será feita levando em conta o contexto histórico, geográfico e cultural da região do Vale do Ribeira-SP, a partir dos resultados das pesquisas de mestrado (2003-2006) e doutorado (2009-2012), ambas desenvolvidas no Departamento de Geografia da Universidade de São Paulo, e dos dados coletados durante o "Ciclo de Audiências Públicas sobre Educação Diferenciada no Vale do Ribeira”, promovido pela Defensoria Pública Estadual e pela Equipe de Articulação e Assessoria às Comunidades Negras (EEACONE), em 2015.
\end{abstract}

Palavras-chave: Políticas educacionais. População quilombola. Diretrizes Curriculares Nacionais para a Educação Escolar Quilombola. Vale do Ribeira.

\section{ABSTRACT \\ QUILOMBOLA SCHOOL EDUCATION: CONSIDERATIONS ON ADVANCES OF EDUCATIONAL POLICIES AND CHALLENGES FOR PEDAGOGICAL PRACTICE IN THE VALE DO RIBEIRA REGION.}

The purpose of this text is to review the advances in the educational policies for the quilombola population, focusing more specifically on the National Curriculum Guidelines (Diretrizes Curriculares Nacionais) for Quilombola School Education. It is intended as well to problematize some of the main challenges and obstacles to be faced in the process of implementing quilombola school education. The analysis undertaken here takes into account the historical, geographical and cultural contexts of the Vale do Ribeira region in the state of São Paulo, based on the results of the author's master degree's dissertation (2003-2006) and doctoral thesis (2009-2012), both developed in the Geography Department of the University of São Paulo, and the data collected during the "Public Hearings Cycle on Differentiated Education in the Vale do Ribeira Region", promoted by the State of São Paulo Public Defender and by EEACONE (Articulation and Advisory Group for Black Communities), in 2015.

\footnotetext{
Doutora em Geografia pela Universidade de São Paulo (USP). Pesquisadora do Núcleo de Pesquisa sobre Populações Humanas em Áreas Úmidas Brasileiras (NUPAUB/USP). Professora no curso de Pedagogia do Instituto Vera Cruz e no Ensino Médio da rede particular de São Paulo. Trabalha com assessoria pedagógica na rede pública e privada de ensino. E-mail: lisangelakati@gmail.com
} 
Keywords: Educational policies. Quilombola population. National Curriculum Guidelines for Quilombola School Education. Vale do Ribeira.

\section{RESUMEN}

\section{EDUCACIÓN ESCOLAR QUILOMBOLA: REFLEXIONES SOBRE LOS AVANCES DE LAS POLÍTICAS EDUCACIONALES Y LOS DESAFÍOS PARA LA PRÁTICA PEDAGÓGICA EN EL VALE DO RIBEIRA-SP}

Este texto tiene el objetivo de tematizar los avances de las políticas educativas para la población quilombola, enfocándose más específicamente en las Directrices Curriculares Nacionales para la Educación Escolar Quilombola, y problematizar algunos de los principales desafíos y obstáculos a ser enfrentados en el proceso de efectividad de la modalidad de educación escolar quilombola en la educación básica. El análisis aquí emprendido se hará teniendo en cuenta el contexto histórico, geográfico y cultural de la región del Vale do Ribeira-SP, a partir de los resultados de las investigaciones de maestría (2003-2006) y de doctorado (2009-2012), ambas desarrolladas en el Departamento de Geografía, de la Universidad de São Paulo, y de los datos recolectados durante el "Ciclo de Audiências Públicas sobre Educação Diferenciada no Vale do Ribeira”, promovido por la Defensoría Pública del estado de São Paulo e por el EEACONE (Equipo de Articulación y Asesoría a las Comunidades Negras), en 2015.

Palabras clave: Políticas educativas. Población quilombola. Directrices Curriculares Nacionales para la Educación Escolar Quilombola. Vale do Ribeira.

\section{Introdução}

Segundo dados da Fundação Cultural Palmares (2008), do Ministério da Cultura, existem hoje no Brasil 3.754 comunidades remanescentes de quilombos, identificadas em maior concentração nos estados de Minas Gerais, Bahia e Maranhão. Outras fontes estimam que existam cerca de cinco mil comunidades.

De acordo com o Art. $2^{\circ}$ do Decreto $n^{\circ}$ $4.887 / 2003$, são considerados quilombos no Brasil: "[..] grupos étnico-raciais segundo critérios de auto-atribuição, com trajetória histórica própria, dotados e relações territoriais específicas, com presunção de ancestralidade negra relacionada com a resistência e opressão histórica sofrida" (BRASIL, 2003a).

Para a Convenção 169 da Organização Internacional do Trabalho (OIT) sobre os Povos Indígenas e Tribais (BRASIL, 2004) e para a Política Nacional de Desenvolvimento Sustentável dos Povos e Comunidades Tradicionais (BRASIL, 2007), os quilombolas são considerados povos ou comunidades tradicionais por serem: grupos cultu- ralmente diferenciados e que se reconhecem como tais; possuidores de formas próprias de organização social; detentores de conhecimentos, tecnologias, inovações e práticas gerados e transmitidos pela tradição; ocupantes e usuários de territórios e recursos naturais como condição para a sua reprodução cultural, social, religiosa, ancestral e econômica.

A questão quilombola entrou, de fato, para a agenda política institucional brasileira somente a partir da Constituição Federal de 1988, como resultado da forte atuação do Movimento Negro na busca da garantia de direitos, do reconhecimento e da valorização do negro na formação social, econômica e cultural do Brasil.

Por meio do Artigo 68 do Ato das Disposições Transitórias Legais, a Constituição Federativa de 1988 garantiu às comunidades quilombolas o direito à propriedade definitiva da terra: "Aos remanescentes das comunidades de quilombos que estejam ocupando suas terras é reconhecida a propriedade definitiva, devendo o Estado emitir-lhes os títulos respectivos" (BRASIL, 1988). A definição da forma 
coletiva de propriedade e o reconhecimento dos direitos territoriais dos grupos étnicos, até então inexistentes, representam avanços significativos na legislação brasileira.

Por meio dos artigos 215 e 216 da mesma Constituição (BRASIL, 1988), as comunidades quilombolas passam a ter garantido o direito à manutenção de sua cultura. O primeiro dispositivo determina que as manifestações culturais afro-brasileiras sejam protegidas pelo Estado, enquanto o segundo considera como patrimônio cultural brasileiro os bens de natureza material e imaterial, incluindo as formas de expressão e o modo de vida dos diferentes grupos formadores da sociedade brasileira.

Entre as principais bandeiras de luta das comunidades quilombolas no Brasil estão as reivindicações para a concretização do direito à terra e permanência nos territórios em que vivem, a manutenção dos conhecimentos tradicionais e da memória coletiva, assegurar a autonomia no modo de produção econômica, a superação do racismo e o acesso à educação de qualidade.

No campo das políticas educacionais, importantes passos legais já foram dados nos últimos anos, visando o reconhecimento e a valorização da diversidade cultural e étnica presente no território brasileiro por meio dos Parâmetros Curriculares Nacionais, mais especificamente com o tema transversal "Pluralidade Cultural"; da Lei $n^{\circ} 10.639 / 2003$ (BRASIL, 2003b); da definição das Diretrizes Curriculares para as Relações Étnico-Raciais e para o Ensino da História e Cultura Afro-brasileira e Africana, por meio da Lei $n^{\circ} 11.645 / 2008$ (BRASIL, 2008), garantindo o Ensino de História e Cultura Afro-Brasileira, Africana e Indígena; e mais recentemente por meio das Diretrizes Curriculares Nacionais para a Educação Escolar Quilombola na Educação Básica (BRASIL, 2012).

Em que medida os avanços em relação à elaboração de leis, resoluções e diretrizes visando a uma educação para a diversidade estão se traduzindo em ações, de fato, efetivas nas salas de aula? Quais as condições necessárias para que os professores possam reesignificar suas práticas pedagógicas visando à implementação da educação escolar quilombola?

A análise aqui empreendida será feita levando em conta o contexto histórico, geográfico e cultural da região do Vale do Ribeira-SP, a partir dos resultados das pesquisas de mestrado (2003-2006) e doutorado (2009-2012) que desenvolvi no Departamento de Geografia da Universidade de São Paulo e dos dados coletados durante o "Ciclo de Audiências Públicas sobre Educação Diferenciada no Vale do Ribeira", promovido pela Defensoria Pública Estadual, localizada no município de Registro, e pela EEACONE (Equipe de Articulação e Assessoria às Comunidades Negras/Vale do Ribeira, em 2015).

A dissertação de mestrado intitulada "Identidade e Territorialidade: os quilombos e a educação escolar no Vale do Ribeira" (NASCIMENTO, 2006), defendida em 2006, teve como foco investigativo o estudo da relação entre o ensino de Geografia e a identidade cultural dos alunos quilombolas da região do Vale do Ribeira. A partir da análise de propostas didáticas de Geografia desenvolvidas nas escolas públicas do município de Eldorado, especialmente na escola do quilombo de Ivaporunduva, das entrevistas realizadas com professores, lideranças e alunos quilombolas, o trabalho buscou identificar elementos que contribuem (ou não) para a (re)construção da identidade cultural das comunidades quilombolas da região do Vale do Ribeira.

Essa pesquisa evidenciou a inexistência, até aquele momento, de propostas didático-pedagógicas que abordassem a diversidade cultural existente no Vale do Ribeira e a história da ocupação quilombola na região.

Com os intensos trabalhos de campo foi possível identificar os desafios e obstáculos enfrentados por essas comunidades. Além da longa luta para garantir os seus direitos previstos constitucionalmente e manter o seu modo de vida tradicional e seus territórios, os quilombolas do Vale do Ribeira lutam para que as escolas onde as crianças, adolescentes e jovens estudam sejam espaços de reconhecimento e valorização de sua cultura e de aprendizagem sobre a história de seu povo.

A pesquisa de doutorado que resultou na tese "O lugar do lugar no ensino de Geografia: um estudo em escolas públicas do Vale do Ribeira-SP" (NASCIMENTO, 2012) investigou sentidos do conceito de lugar para alunos e professores da rede pública do Vale do Ribeira. O objetivo principal foi compreender se o lugar vivido pelos alunos é estudado nas escolas públicas, contribuindo para 
aprendizagens significativas, construção de vínculos e para a compreensão complexa do lugar.

Os múltiplos olhares dos diferentes sujeitos dessa pesquisa - professores e alunos ${ }^{1}$ - nos mostraram que o lugar vivido pelos alunos parece estar desconectado do mundo estudado na escola. Tanto os alunos de Ensino Fundamental (Anos Finais) quanto os de Ensino Médio abordados evidenciaram pouco conhecimento sobre o Vale do Ribeira e sobre a diversidade sociocultural representada pelas populações tradicionais presentes na região. A partir do desenvolvimento de oficinas pedagógicas com os professores, foi possível constatar que a maioria dos professores de Geografia que atua na região, em sua formação inicial, não teve oportunidade de estudar o seu lugar vivido e não se apropriou das teorias para compreender a categoria de lugar como pressuposto do ensino de Geografia, bem como de metodologias para tornar o lugar objeto de conhecimento na escola.

O "Ciclo de Audiências Públicas sobre Educação Diferenciada no Vale do Ribeira", realizado ao longo de 2015 em quatro municípios da região (Cananeia, Itaoca, Eldorado e Barra do Turvo), contribuiu para fomentar o debate entre as populações indígenas, caiçaras, quilombolas e caboclas sobre o direito a uma educação de qualidade, incluindo tanto aspectos relacionados à infraestrutura (construção de escolas ou mais salas de aulas, de bibliotecas etc.), bem como o direito a um currículo que contribua para a aprendizagem da história dos diferentes povos que formam a região do Vale do Ribeira e para a valorização da identidade cultural e étnica dos alunos e das alunas.

A partir dos depoimentos de representantes das diversas comunidades quilombolas da região, incluindo os municípios de Cananeia, Iguape, Registro, Eldorado, Itaoca, Iporanga e Barra do Turvo, foi possível identificar diversas demandas, como, por exemplo: merenda escolar adequada aos hábitos alimentares das crianças quilombolas; cursos de formação de professores para que possam lidar com as especificidades da educação escolar quilombola; implementação de propostas didáticas

1 No total foram abordados 287 alunos de Ensino Fundamental (Anos Finais) e Ensino Médio de escolas públicas do município de Cajati.

2 Promovido pela Defensoria Pública do Estado de São Paulo, localizada no município de Registro. que reconheçam como conteúdos de aprendizagem o modo de vida, os valores culturais, a tradição, a luta pela terra, entre outros aspectos; a elaboração de materiais didáticos; e a participação das comunidades na elaboração do projeto político pedagógico.

Além das denúncias feitas oralmente durante cada audiência, lideranças de 25 comunidades quilombolas de diferentes municípios da região ${ }^{3}$ responderam a um questionário elaborado pela Defensoria Pública Estadual sobre a situação da educação escolar. Esses dados foram tabulados e sistematizados no "Relatório da Situação da Educação nas Comunidades Quilombolas do Vale do Ribeira" (PERES, 2017), elaborado pelo grupo de pesquisa "História e Memória para o Desenvolvimento", coordenado pela professora Alice Miguel de Paula Peres, da Universidade Federal de São Carlos.

Visando promover o diálogo entre os avanços das políticas educacionais - focando mais especificamente na Resolução CEB/CNE nº 08/2012 (BRASIL, 2012), que define as Diretrizes Curriculares Nacionais para a Educação Escolar Quilombola na Educação Básica - e os desafios para a implementação da educação escolar quilombola no Vale do Ribeira, traçaremos um panorama - ainda bastante geral - sobre a situação atual da educação quilombola na região.

\section{Vale do Ribeira: características gerais, número de comunidades quilombolas, situação fundiária e conflitos}

A região do Vale do Ribeira, localizada entre os estados do São Paulo e Paraná, abriga o maior número de comunidades de quilombos do estado de São Paulo. De acordo com os dados da Fundação Instituto de Terras do Estado de São Paulo (2015), atualmente, existem 58 comunidades quilombolas no estado, 37 delas no Vale do Ribeira, ${ }^{4}$ as quais encontram-se em diferentes situações em relação ao

3 Cananeia: Mandira e Porto Cubatão; Barra do Turvo: Cedro, Reginaldo, Ilhas; Eldorado: Abobral Margem Direita, Abobral Margem Esquerda, Andre Lopes, Ostra, Pedro Cubas, Sapatu, Pedro Cubas de Cima, São Pedro, Engenho, Galvão, Ivaporunduva e Poça; Iguape: Morro Seco e Aldeia; Iporanga: Bombas, Maria Rosa, Nhuguara, Pilões e Piririco; Registro: Paropeba.

4 Já as estimativas da Equipe de Articulação e Assessoria às Comunidades Negras (EAACONE) apontam para a existência de aproximadamente 60 comunidades somente nesta região. 
processo de regularização fundiária (ver Anexo 1). Deste total de comunidades existentes no estado de São Paulo, apenas seis receberam o título de pro- priedade da terra, todas elas localizadas no Vale do Ribeira: Ivaporunduva, Maria Rosa, Pedro Cubas, Pilões, São Pedro e Galvão, conforme Figura 1.

Figura 1 - Mapa das comunidades quilombolas no Vale do Ribeira - Estado de São Paulo

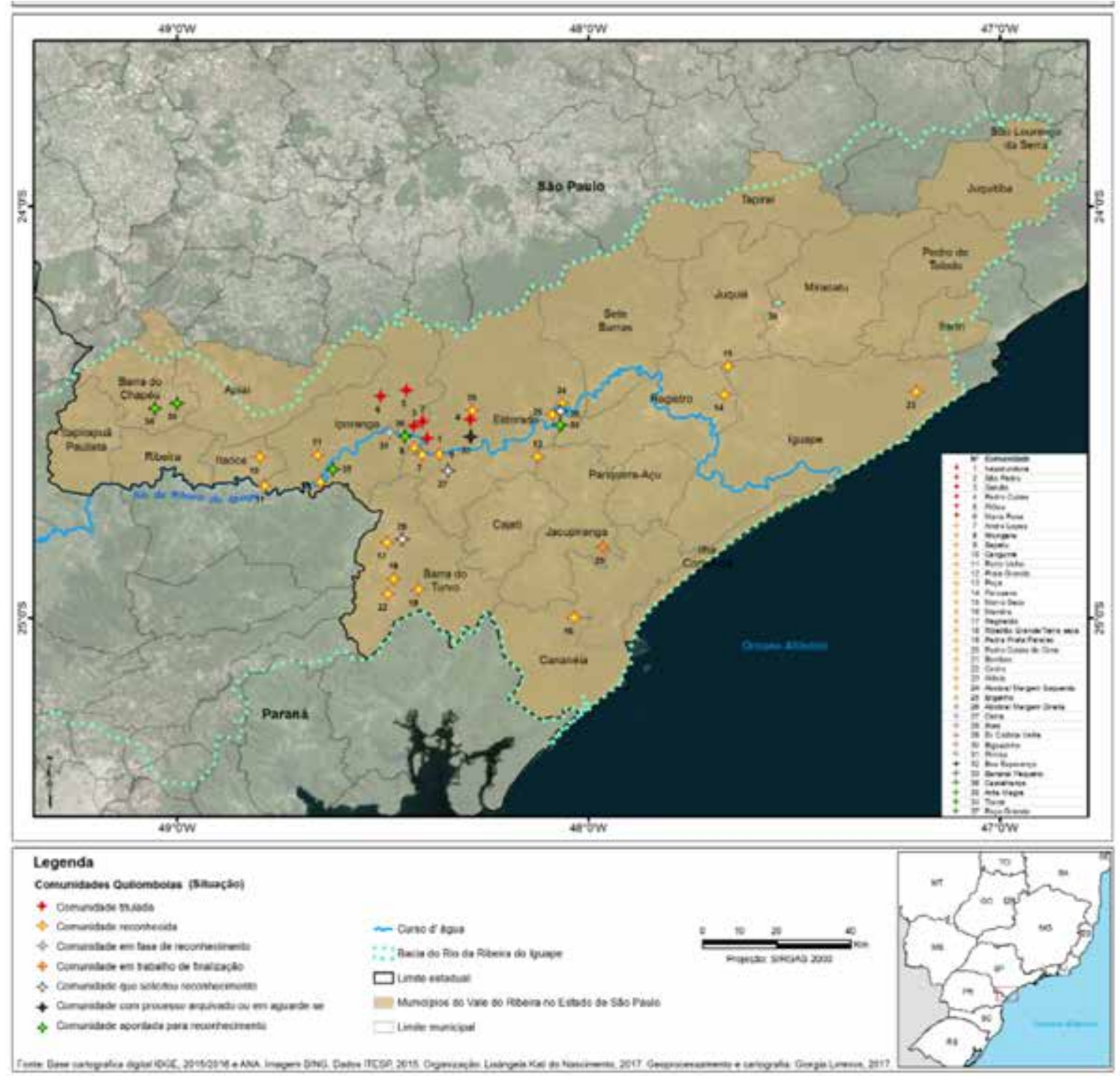

Fonte: Limnios (2017).

Esse número expressivo de comunidades quilombolas na região do Vale do Ribeira se explica pelo ciclo da mineração durante os séculos XVII e XVIII e a significativa produção de arroz no século XIX. Assim, formadas por escravos foragidos, libertos ou abandonados, muitas das comunidades negras do Vale do Ribeira assentaram-se em terras próximas às margens do rio Ribeira de Iguape ou em áreas de difícil acesso, em busca de autonomia e defesa dos preconceitos e da hostilidade da sociedade branca. Organizaram-se de modo a poder reproduzir-se social e materialmente por meio de relações de solidariedade, ajuda mútua e do acesso comum à terra (NASCIMENTO, 2006).

Cada comunidade apresenta características específicas, próprias de um modo de convivência entre os membros do grupo e da articulação com a sociedade envolvente. No entanto, algumas carac- 
terísticas comuns podem ser observadas na maioria das comunidades, sendo possível compreendê-las num âmbito geral. É importante ressaltar que discutir a organização social, o modo de vida e a identidade cultural das comunidades em seu conjunto não significa a anulação das especificidades de cada uma delas 5 .

As comunidades quilombolas do Vale do Ribeira caracterizam-se, como outras populações tradicionais, pelo forte vínculo com o território em que vivem, onde se verifica um alto grau de preservação dos recursos naturais. A maioria dessas comunidades tem sua estrutura produtiva baseada na agricultura de subsistência, que assegura os produtos básicos para o consumo familiar, e em uma pequena comercialização de parte de sua produção, a fim de suprir necessidades outras que a agricultura praticada não consegue proporcionar.

As relações sociais são alicerçadas sob laços de parentesco e os trabalhos cotidianos, especialmente os desenvolvidos na roça, são organizados sob base familiar. Muitas famílias ocupam-se da agricultura, sendo a familiar a principal encontrada. A terra é de uso comum ${ }^{6}$ e cada família ocupa pequenos lotes para desenvolver sua roça, com plantações de mandioca, feijão, milho, bata doce, inhame etc., e criam seus animais.

É importante compreender que algumas das características do Vale do Ribeira conferem determinadas especificidades em relação aos conflitos vivenciados pelas comunidades quilombolas. A região caracteriza-se como uma área de grande relevância ambiental em nosso país, pois concentra as maiores manchas contínuas de Mata Atlântica do

5 Os diversos trabalhos de campo para a realização da pesquisa de mestrado nos proporcionaram um conhecimento significativo das comunidades de Ivaporunduva, Pedro Cubas, André Lopes, Sapatu, Nhuguara, São Pedro e Mandira. Com a aproximação e vivência no cotidiano das comunidades, foi possível perceber traços comuns, principalmente em relação às formas de utilização e manejo dos recursos naturais. No entanto, em relação à organização política para o enfrentamento de problemas sociais e econômicos, foi possível perceber diferenças como os diferentes graus de mobilização em torno das associações.

6 Esse atributo constitui importante característica das comunidades de quilombos no Brasil. Almeida (1999), em seus estudos nas comunidades quilombolas do Maranhão, constatou que as terras de uso comum abarcam uma enorme quantidade de situações de apropriação dos recursos naturais (solo, recursos hídricos e florestais) que são utilizados a partir de uma diversidade de formas, incluindo combinação entre o uso e a propriedade, entre o caráter privado e comum perpassados pelos fatores históricos e de parentesco, por exemplo (O'DWYER, 2002).
Brasil (um dos biomas mais ameaçados do planeta), uma grande área de restinga e de manguezais ainda bem preservados. Soma-se a presença de um dos mais importantes complexos espeleológicos do Brasil e o maior número de sítios arqueológicos do estado de São Paulo. Para preservar o rico patrimônio ambiental, grande parte da região está protegida por alguma categoria de Unidade de Conservação (UC).

A partir da década de 1950, a criação de UCs por toda a região, incluindo parques e áreas de proteção ambiental e de vida silvestre, principalmente, impôs inúmeras restrições às práticas rotineiras de utilização dos recursos naturais, alterando de maneira significativa o modo de vida das populações quilombolas. Para Diegues (2000), esse modelo de preservação dos recursos naturais ignora o saber tradicional dessas comunidades sobre o meio do qual fazem parte, impondo uma série de restrições que, na maioria das vezes, são conflitantes com o modo como tais comunidades utilizam os recursos naturais. Diante desse quadro, muitos quilombolas tornaram-se assalariados nas fazendas próximas. Algumas comunidades se inseriram na produção de banana, conseguindo assegurar, assim, formas de sustentabilidade próprias, como é o caso do quilombo de Ivaporunduva, localizado no município de Eldorado.

Complementando o conjunto de intervenções no modo de vida tradicional, a partir da década de 1980, as comunidades quilombolas localizadas às margens do rio Ribeira de Iguape passam a correr o risco de perderem seus territórios devido à possibilidade de construção de barragens neste rio ${ }^{7}$. Vale ressaltar que o rio Ribeira sempre foi referência para todas as comunidades rurais ao longo dele assentadas; para as comunidades quilombolas, esse rio desempenha papel fundamental como meio de comunicação, transporte, pesca e lazer e para a perpetuação da dimensão simbólica dos habitantes dessas áreas (STUCCHI, 1998).

7 Havia dois projetos para a construção de quatro barragens no rio Ribeira de Iguape: um deles é o projeto de construção da barragem Tijuco Alto, da Companhia Brasileira de Alumínio (CBA), do Grupo Votorantim, com o objetivo de produção de energia elétrica, em caráter privado, para aumentar a exportação de alumínio para os EUA, Japão e Europa. O outro projeto é da Companhia Energética do Estado de São Paulo (CESP), para a construção de três barragens: Itaoca, Funil e Batatal, com o objetivo de aproveitamento múltiplo, ou seja, para a geração de energia e controle de cheias no rio Ribeira de Iguape. 
Os problemas enfrentados, como as questões ambientais, as dificuldades econômicas e a questão das barragens, entre outros, sempre foram discutidos e tratados abertamente nas comunidades e são motivos de diálogo em vários momentos da vida cotidiana. As crianças, dessa forma, vivenciam essas problemáticas no seu dia a dia. No entanto, conforme depoimentos de diversas lideranças quilombolas coletados durante a pesquisa de mestrado (NASCIMENTO, 2006) e durante as audiências públicas (DEFENSORIA PÚBLICA DO ESTADO DE SÃO PAULO, 2015), quando chegam às escolas, suas experiências sociais e sua identidade cultural não são reconhecidas, sendo, muitas vezes, desqualificadas.

Nesse contexto, a educação escolar tornou-se uma grande preocupação das lideranças quilombolas. Compreendendo a importância da educação formal, atualmente as comunidades lutam para a implementação das Diretrizes Curriculares Nacionais para a Educação Escolar Quilombola na Educação Básica (BRASIL, 2012).

\section{Dos princípios da Educação Escolar Quilombola à situação atual das escolas que atendem aos alunos quilombolas do Vale do Ribeira}

Em 2012, a Câmara de Educação Básica (CEB) do Conselho Nacional de Educação (CNE) aprovou as Diretrizes Curriculares Nacionais para a Educação Escolar Quilombola na Educação Básica, entendida como modalidade de educação que compreende as escolas quilombolas (aquelas que estão localizadas em territórios quilombolas) e as escolas que atendem estudantes oriundos de comunidades quilombolas.

A Educação Escolar Quilombola compreende a Educação Infantil, o Ensino Fundamental, o Ensino Médio, a Educação Especial, a Educação Profissional Técnica de Nível Médio, a Educação de Jovens e Adultos, inclusive a Educação a Distância, e destina-se ao atendimento das populações quilombolas rurais e urbanas.

É importante compreendermos que a modalidade da educação quilombola está inserida no contexto mais amplo de buscas para garantir espaços institucionais de educação formal com vistas à superação da posição subalterna da população negra na sociedade brasileira, legitimada ao longo da história, inclusive, pelo nosso sistema educacional. Portanto:

É imprescindível considerar que a garantia da Educação Escolar Quilombola como um direito das comunidades quilombolas rurais e urbanas vai além do acesso à educação escolar. Significa a construção de um projeto de educação e de formação profissional que inclua: a participação das comunidades quilombolas na definição do projeto político-pedagógico e na gestão escolar; a consideração de suas estruturas sociais, suas práticas socioculturais e religiosas, um currículo aberto e democrático que articule e considere as suas formas de produção de conhecimento; a construção de metodologias de aprendizagem adequadas às realidades socioculturais das comunidades; a produção de material didático-pedagógico contextualizado, atualizado e adequado; a alimentação que respeite a cultura alimentar das comunidades; a infraestrutura escolar adequada e em diálogo com as realidades regionais e locais; o transporte escolar de qualidade; a formação específica dos professores quilombolas, em serviço e, quando for o caso, concomitante à sua escolarização; a inserção da realidade sociocultural e econômica das comunidades quilombolas nos processos de formação inicial e continuada de docentes quilombolas e não quilombolas que atuarão ou receberão estudantes dessas comunidades na educação. (BRASIL, 2012).

Os princípios acima que fundamentam as Diretrizes Curriculares Nacionais para a Educação Escolar Quilombola na Educação Básica, por meio da Resolução CEB/CNE no 08/2012, nos mostram que a garantia à educação escolar quilombola como um direito das comunidades quilombolas rurais e urbanas é maior que apenas o acesso à educação escolar, incluindo formação inicial e continuada de professores quilombolas e não quilombolas, produção de material didático contextualizado, transporte escolar de qualidade, currículo aberto e flexível, participação da comunidade na elaboração do projeto político pedagógico e na gestão escolar, entre outros princípios.

No escopo deste trabalho, nos restringiremos a analisar, ainda que de maneira sucinta, cinco aspectos fundamentais fortemente mencionados pelas lideranças durante as audiências públicas: 
acesso às unidades escolares, currículo, formação de professores, projeto político pedagógico e gestão escolar.

\section{Acesso às unidades escolares}

Segundo dados do Conselho Estadual de Educação Quilombola (SÃO PAULO, 2013), apenas 26 comunidades quilombolas em todo o estado de São Paulo têm escolas em seus territórios; destas, 24 são municipais (administradas pelas prefeituras) e apenas duas são estaduais. De acordo com a Resolução CEB/CNE n ${ }^{\circ}$ 08/2012 (BRASIL, 2012), a educação escolar é obrigação do Estado, portanto, a Secretaria Estadual de Educação precisa atender a todas as escolas com demanda quilombola.
Em 2005 foi fundada a Escola Estadual Maria Chules Princesa, a primeira escola quilombola do Vale do Ribeira, fruto da luta das comunidades dos municípios de Eldorado e Iporanga. Localizada no quilombo de André Lopes, em Eldorado, essa escola consegue atender alunos de seis comunidades, sendo elas: Ivaporunduva, São Pedro, Galvão, Nhunguara, Sapatu e André Lopes.

No restante da região do Vale do Ribeira, encontramos situações adversas em relação à educação escolar destinada à população quilombola, marcada tanto pelo funcionamento precário das escolas existentes, quanto pela inexistência de escolas nas comunidades ou de alguma etapa de ensino, conforme podemos verificar nos dados apresentados no Quadro 1.

Quadro 1 - Unidades Escolares, número de crianças e número de estudantes

\begin{tabular}{|c|c|c|c|c|}
\hline \multicolumn{5}{|c|}{ Comunidades/ Escolaridade } \\
\hline & SIM & NÃO & \multirow{2}{*}{$\mathrm{N}^{\mathrm{o}}$ de crianças } & \multirow{2}{*}{$\mathrm{N}^{\mathrm{o}}$ de estudantes } \\
\hline Unidade Escolar na comunidade & 16 & 8 & & \\
\hline Creches & 2 & 23 & 179 & 4 \\
\hline Educação Infantil (4 a 5 anos) & 14 & 11 & 175 & 156 \\
\hline $\begin{array}{l}\text { Ensino Fundamental - Anos Iniciais } \\
\text { ( } 6 \text { a } 8 \text { anos) }\end{array}$ & 14 & 11 & 236 & 284 \\
\hline Ensino Fundamental (9 a 14 anos) & 4 & 21 & 324 & 243 \\
\hline Ensino Médio (15 a 17 anos) & 3 & 22 & 239 & 201 \\
\hline \multicolumn{3}{|l|}{ Total } & 1153 & 888 \\
\hline
\end{tabular}

Fonte: Peres (2017, p. 10).

Os dados acima mostram que em 16 comunidades há unidades escolares ${ }^{8}$ e em apenas duas há creches. Catorze comunidades contam com Educação Infantil e os Anos Iniciais do Ensino Fundamental. Já os Anos Finais do Ensino Fundamental estão presentes em apenas quatro comunidades e o Ensino Médio, em três. Em relação à Educação de Jovens e Adultos (EJA), foi declarado a presença em apenas uma comunidade. Em oito comunidades

8 Das 25 comunidades que responderam ao questionário, uma não respondeu essa questão. localizadas nos municípios de Barra Turvo, Eldorado e Iporanga, não há unidade escolar.

A falta de unidades escolares ou de algum segmento da escolaridade nas comunidades contribui para a evasão escolar, pois para dar continuidade aos estudos os alunos precisam se deslocar para outros bairros, outras comunidades ou para a zona urbana. Certamente, muitas dificuldades surgem neste processo, sendo algumas delas de ordem estrutural como, por exemplo, a travessia do rio Ribeira em alguns casos e o/ou deslocamento a pé 
até o acesso ao transporte escolar, a necessidade de ter que morar longe da família, entre outras dificuldades.

De acordo com os dados levantados nesse mesmo questionário, nessas oito comunidades em que não há escolas encontram-se aproximadamente 267 famílias com 54 crianças de até 3 anos, 55 de 4 a 5 anos, 72 de 6 a 8 anos, 324 de 9 a 14 anos e 239 de 15 a 17 anos, totalizando um universo de 744 crianças e adolescentes. Isso significa que estes estudantes se descolocam diariamente para estudar em unidades do entorno, necessitando de transporte escolar, ponto bastante comentado e criticado pelas lideranças durante as audiências públicas.

A qualidade do transporte escolar apontada pelas lideranças que responderam ao questionário nos chama atenção, conforme podemos verificar pelos dados apresentados no Gráfico 1 .

Gráfico 1 - Quantidade de estudantes com transporte inadequado em relação ao total de estudantes segundo o nível de escolaridade

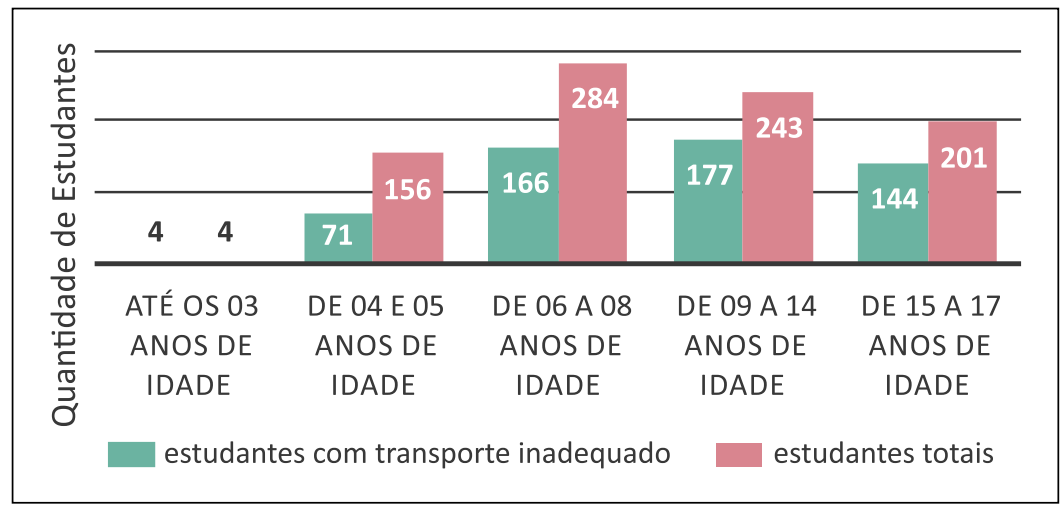

Fonte: Peres (2017, p. 14).

Estão expostos ao transporte inadequado $71(45,5 \%)$ dos 156 estudantes de 4 a 5 anos; 162 $(58,4 \%)$ dos 284 estudantes de 6 a 8 anos; 177 $(72,8 \%)$ dos 243 alunos de 9 a 14 anos; e 144 $(71,6 \%)$ dos 201 estudantes de 15 a 17 anos.

Os problemas que afetam a qualidade do transporte escolar ofertado pelo poder público, ainda de acordo com as lideranças que responderam ao questionário são: estradas com problemas; ônibus sem manutenção, incluindo a falta de cinto de segurança, pneus sem condições de tráfego; quebra frequente de ônibus; profissionais despreparados para o trabalho com estudantes e que dirigem em alta velocidade; transporte com superlotação; restrições de horários e dos pontos de partida e chegada, forçando os alunos andarem até $15 \mathrm{~km}$; necessidade de balsas.

É importante mencionar um caso mais grave ainda: os alunos da comunidade de Bombas estão impossibilitados de terem aula, ou seja, estão sofrendo violações a direitos fundamentais por omissão do Estado. Esta comunidade, localizada no município de Iporanga, onde vivem cerca de
85 pessoas, não conta com água encanada, rede de esgoto, energia elétrica, telefone e estrada. Só é possível acessar a comunidade por meio de trilha que não permite a circulação de veículos automotores. Em Parecer elaborado pela Defensoria Pública Estadual de Registro, enviado à Secretaria Estadual de Educação em março de 2016, o defensor público Andrew Toshio nos mostra a situação de urgência em que se encontra essa comunidade:

[...] há anos o Estado de São Paulo não atende a Comunidade Quilombola de Bombas, não oferecendo vagas no ensino fundamental, anos finais, no Ensino Médio e na modalidade Educação de Jovens e Adultos, totalizando 21 potenciais alunos excluídos do sistema de educação para ano de 2017. (DEFENSORIA PÚBLICA DO ESTADO DE SÃO PAULO, 2016).

Neste mesmo documento, o defensor público recomenda:

À Secretaria da Educação do Estado de São Paulo, que assegure a prestação do serviço público de educação na Comunidade Quilombola de Bombas, 
localizada na cidade de Iporanga, disponibilizando vagas no ensino fundamental, anos finais, no ensino médio e na modalidade Educação de Jovens e Adultos, ainda que por meio da adoção e regulamentação de metodologia e pedagogia alternativas, como o sistema modular de ensino, desde que respeitadas as necessidades peculiares das famílias e dos estudantes da comunidade. (DEFENSORIA PÚBLICA DO ESTADO DE SÃO PAULO, 2016).

Em 20 de outubro de 2016, em reunião ordinária do Conselho Estadual de Educação Escolar Quilombola, da qual participamos, a Secretaria Estadual de Educação garantiu que a questão seria resolvida por meio da regularização da criação e adoção do sistema pedagógico alternativo contemplando as peculiaridades da comunidade de Bombas, dada a inviabilidade do deslocamento diário dos estudantes devido à falta de estrada. No entanto, até o presente momento, a situação permanece inalterada e, portanto, os alunos continuam sem aula.

\section{Currículo}

Por meio da Resolução CEB/CNE n. 8/2012 (BRASIL, 2012), está garantido às populações quilombolas o direito a uma escola que assegure a formação básica comum, mas que respeite, valorize e, sobretudo, crie condições para que a história de luta desse povo, a memória do grupo, os seus valores culturais, as especificidades de seu modo de vida, bem como suas contribuições históricas na formação do nosso país, se tornem conteúdos de ensino e aprendizagem na escola. Portanto, faz-se necessário construir um currículo escolar aberto, flexível e de caráter interdisciplinar, elaborado de modo a possibilitar a articulação entre os conhecimentos escolares e os conhecimentos das comunidades.

$\S 1^{\circ}$ A Educação Escolar Quilombola na Educação Básica:

I. organiza precipuamente o ensino ministrado nas instituições educacionais, fundamentando-se, informando-se e alimentando-se:

a) da memória coletiva;

b) das línguas reminiscentes;

c) dos marcos civilizatórios;

d) das práticas culturais; e) das tecnologias e formas de produção do trabalho;

f) dos acervos e repertórios orais;

g) dos festejos, usos, tradições e demais elementos que conformam o patrimônio cultural das comunidades quilombolas de todo o país;

h) da territorialidade. (BRASIL, 2012, p. 03).

Todos esses aspectos (línguas reminiscentes, práticas culturais, repertórios culturais etc.) são estruturantes da identidade cultural quilombola. Essa identidade é constituída por diversos fatores, entre eles, a ancestralidade comum ao grupo, a autoidentificação ou autoclassificação, elementos linguísticos e religiosos, organização política própria e um sistema particular de produção econômica. É importante ressaltar que não são apenas os elementos distintivos que compõem a organização identitária do grupo, mas também os elementos contrastivos, ou seja, aqueles que são (re)construídos ou (re) afirmados quando o grupo está em confronto com grupos externos. No caso do Vale do Ribeira, por exemplo, os projetos de barragens para o rio Ribeira de Iguape e a implementação das políticas ambientais restritivas, como mencionamos anteriormente, forçou as comunidades quilombolas a assumirem uma identidade por meio da qual reivindicam o direito à terra, garantido constitucionalmente. $\mathrm{Ou}$ seja, a identidade também é construída a partir da necessidade de lutar pelo território em que vivem.

O território, para as comunidades quilombolas, não constitui apenas um aglomerado físico de terras férteis, como muitas vezes encontramos nas descrições generalizantes dos livros didáticos. Esse território é uma porção do espaço geográfico onde ocorre tanto a produção material dos meios de subsistência quanto a produção de significados simbólicos do grupo. Conforme pontua Milton Santos (1998, p. 61), “[...] o território em que vivemos é mais que um simples conjunto de objetos, mediante os quais trabalhamos, circulamos, moramos, é também um dado simbólico". Assim, torna-se necessário que questões relacionadas ao território quilombola e, portanto, à territorialidade, façam parte do currículo das escolas quilombolas.

A memória coletiva é outro elemento que fortalece a identidade cultural, pois é por meio dela que as histórias são contadas e reconstruídas. E essas histórias são marcadas pelo lugar vivido por cada 
comunidade. É a partir dele (lugar vivido) que o negro quilombola se define, não como um sujeito genérico, mas como integrante de uma comunidade ou grupo que ocupa um determinado território.

Durante as audiências públicas, as lideranças quilombolas criticaram massivamente o currículo seguido nas escolas onde as crianças, os adolescentes e os jovens quilombolas estudam - incluin- do a Escola Estadual Maria Chules Princesa -, o qual não traz aspectos da cultura e do modo de vida quilombola, bem como os materiais didáticos utilizados pelos professores são os mesmos enviados para todas as escolas públicas do estado de São Paulo, não abordando questões específicas do Vale do Ribeira. Os dados do Gráfico 2 traduzem essa crítica.

Gráfico 2 - Calendário escolar; costumes e as tradições da comunidade como parte do ensino e do conteúdo das aulas e; história da luta quilombola no Brasil e da luta das comunidades do Vale do Ribeira como parte do conteúdo das aulas

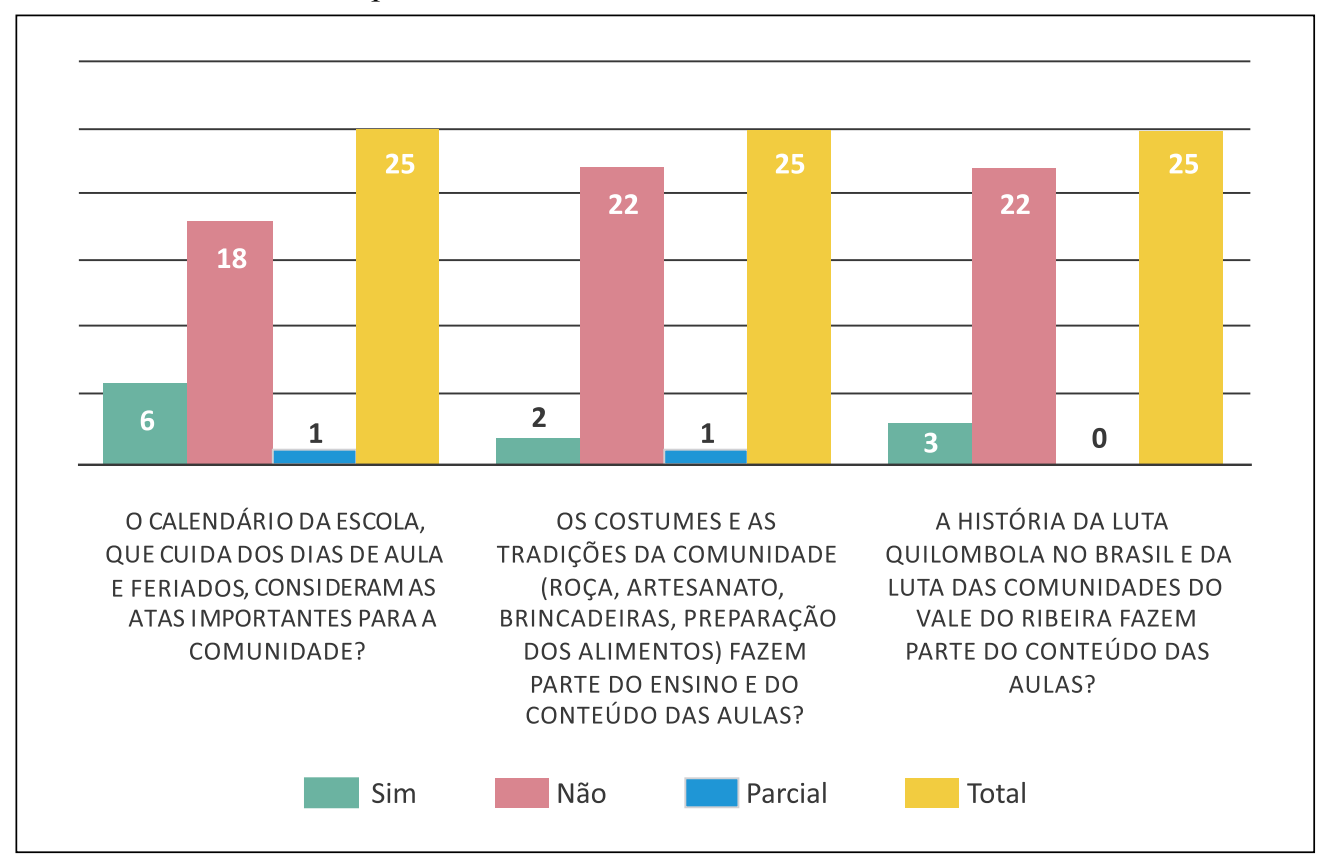

Fonte: Peres (2017, p. 21).

Como podemos notar, lideranças de 22 comunidades (entre as 25 que responderam ao questionário) apontam que os costumes e as tradições das comunidades (roça, artesanato, brincadeiras, preparação dos alimentos) não fazem parte do ensino e do conteúdo das aulas, bem como a história da luta quilombola no Brasil e da luta das comunidades do Vale do Ribeira. É importante lembrar que desde 1997 os Parâmetros Curriculares Nacionais (PCNs) (BRASIL, 1997) já apontavam para a necessidade de garantir um tratamento objetivo e compreensivo daqueles aspectos considerados relevantes em cada região e localidade.

A identidade cultural e social dos alunos quilombolas (e todos os outros alunos) é uma cons- trução, portanto, a escola enquanto instituição privilegiada de formação tem um papel fundamental neste processo. É preciso que a escola considere os interesses, os valores, a cultura e o conhecimento dos sujeitos envolvidos no processo educativo e reconheça o lugar vivido dos alunos como objeto de aprendizagem na escola.

Se a criança, adolescente ou jovem vai para a escola e não se reconhece nas propostas didáticas desenvolvidas, o que significa dizer que o seu modo de vida, o seu modo de falar, os seus hábitos alimentares, entre outros aspectos de sua cultura, não são valorizados naquele espaço institucional, possivelmente esse aluno não vai querer se identificar como pertencente ao seu grupo cultural. Se 
a história da colonização e da escravidão negra no Brasil for estudada apenas do ponto de vista do colonizador, estaremos contribuindo para que o aluno quilombola não se identifique como negro. Se as discussões sobre as barragens e sobre a titulação das terras quilombolas, por exemplo, não aparecerem de maneira intencional nas propostas didáticas como conteúdos de aprendizagem, a escola está perdendo a oportunidade de contribuir para o fortalecimento ou (re)construção da identidade cultural dos alunos quilombolas e para a construção da cidadania.

Formar cidadão significa dar condições ao aluno de se reconhecer-se como sujeito social que tem uma história, que tem um conhecimento prévio do mundo e é capaz de construir o seu conhecimento. Significa compreender a sociedade que vive sua história e o espaço por ela produzido como resultado da vida dos homens. Isso tem de ser feito de modo que o aluno se sinta parte integrante daquilo que está estudando. (CALLAI, 2003, p. 78).

Outro aspecto relacionado ao currículo e fortemente mencionado pelas lideranças quilombolas durante as quatro audiências públicas refere-se ao calendário escolar. De acordo com as Diretrizes Curriculares Nacionais para a Educação Escolar Quilombola na Educação Básica (BRASIL, 2012), o calendário das escolas quilombolas e daquelas que atendem alunos quilombolas deve se adequar às peculiaridades locais, inclusive climáticas, econômicas e socioculturais das comunidades. E, ainda, deve incluir as datas consideradas mais significativas para a população negra e para a população quilombola, de acordo com a região e a localidade. Portanto, as comunidades precisam ser consultadas em relação às datas das festas tradicionais, festivais locais, celebrações etc.

A melhor forma de reorganizar o calendário é discuti-lo com a comunidade e os estudantes. Para tal, o assunto poderá ser levado para discussão nas assembleias escolares, com o Colegiado ou Conselho Escolar, com o Grêmio Estudantil, bem como ser tema das reuniões e visitas à comunidade. Essa poderá ser uma estratégia da escola para o conhecimento, a consulta e a escuta atenta do que é considerado mais marcante pela comunidade a ponto de ser rememorado e comemorado pela escola. Cabe destacar que as comemorações deverão ser precedi- das e acompanhadas de uma discussão pedagógica com os estudantes sobre o seu sentido e o seu significado, sua relação com a sociedade em geral e a comunidade quilombola em específico. Poderá ser, portanto, a culminância de atividades realizadas em sala de aula com os estudantes, projetos de trabalho, projetos de áreas, de disciplinas específicas ou atividades interdisciplinares. (BRASIL, 2012a, p. 44)

No entanto, não está acontecendo isso em todas as comunidades, como podemos verificar pelos dados do Gráfico 2, que indica que somente em seis comunidades o calendário da escola considera as datas importantes para a comunidade, enquanto em 18 comunidades $(72 \%)$ isso não ocorre.

\section{Formação de professores}

De acordo com a Resolução CEB/CNE $n^{\circ}$ 08/2012, para a efetivação da educação escolar quilombola é necessário:

[...] pedagogia própria em respeito à especificidade étnico-cultural de cada comunidade e formação específica de seu quadro docente, observados os princípios constitucionais, a base nacional comum e os princípios que orientam a Educação Básica brasileira. Na estruturação e no funcionamento das escolas quilombolas, deve ser reconhecida e valorizada a diversidade cultural. (BRASIL, 2012).

Portanto, faz-se necessário que professores e gestores da escola compreendam os sentidos dos elementos culturais para a vida das comunidades quilombolas para que, a partir daí, compreendam o papel da escola, do currículo, dos materiais didáticos utilizados e das atividades propostas em sala de aula no fortalecimento da identidade sociocultural dos alunos.

Para Benedito da Silva, conhecido como Ditão, um dos importantes líderes do quilombo de Ivaporunduva, a escola deveria exercer papel fundamental na valorização da identidade quilombola, mas acaba por desqualificar a experiência de vida e os valores culturais quilombolas.

Segundo depoimentos coletados durante a pesquisa de mestrado, as escolas, na maioria das vezes, desqualificam a história de vida das crianças e desvalorizam a forma de trabalho desenvolvido por seus pais, como o trabalho na lavoura, e não proporcionam conhecimento suficiente e preparató- 
rio para a vida na cidade. $\mathrm{O}$ trecho abaixo da carta escrita, em 2002, pelas comunidades quilombolas do Vale do Ribeira e enviada para o Ministério da Educação corrobora com esses depoimentos.

As escolas que nossos filhos frequentam desvalorizam nossa experiência de quilombolas e nossa cultura, afastando-os dos valores da comunidade.

A maioria dos professores, sem nos conhecer, menospreza os nossos costumes reforçando a discriminação racial.

O nível de ensino que a escola tem oferecido é fraco e nossos filhos passam de ano sem saber ler e escrever. O que nossos filhos aprendem na Escola, os afasta dos hábitos e costumes da comunidade, tira-lhes o incentivo do trabalho na lavoura e não dá conhecimentos para trabalhar e sobreviver na cidade. Isso faz com que eles não se sintam mais pertencentes à comunidade e menos ainda à cidade .

Para Ditão, por não conhecer as comunidades e os costumes, a maioria dos professores que atuam nessas escolas não contribui para a superação da discriminação racial. Certamente, isso dificulta a formação de uma reflexão crítica e sem preconceitos, tanto por parte dos alunos (quilombolas ou não), como também dos próprios educadores, pois os quilombolas acabam sendo encarados de forma estereotipada, como aponta Oriel Rodrigues, outra liderança do quilombo de Ivaporunduva:

Toda vez que se fala em quilombos, tem um rótulo e esse rótulo tem sempre uma direção negativa. Quando chega na cidade, você percebe que as pessoas veem a gente como o pessoal do quilombo que é contra o progresso, que são contras barragens, então a barragem vai trazer o progresso e os quilombolas são contra, então são pobres. Tudo nessa linha, que faz com as pessoas desconheçam o quilombo. (NASCIMENTO, 2006, p. 75).

As Diretrizes Curriculares Nacionais para a Educação Escolar Quilombola na Educação Básica explicitam que o poder público, em diálogo com o movimento quilombola, deverá garantir, além da construção de um currículo diferenciado, financiamento para investir em arquitetura escolar, alimentação escolar, elaboração de material didático e formação de professores e gestores escolares.

9 Trecho da carta escrita pelas comunidades quilombolas do Vale do Ribeira e encaminhada ao Ministério da Educação em 2002.
Assim, a União, os Estados, o Distrito Federal e os Municípios deverão, de acordo com as deliberações da Conferência Nacional de Educação (BRASIL, 2010):

Subsidiar a abordagem da temática quilombola em todas as etapas da Educação Básica, pública e privada, compreendida como parte integrante da cultura e do patrimônio afro-brasileiro, cujo conhecimento é imprescindível para a compreensão da história, da cultura e da realidade brasileiras;

Promover a formação específica e diferenciada (inicial e continuada) aos/às profissionais das escolas quilombolas, propiciando a elaboração de material didático-pedagógico contextualizados com a identidade étnico-racial do grupo;

Garantir aos professores/aos quilombolas a sua formação em serviço e, quando for o caso, concomitantemente a sua própria escolarização.

No entanto, conforme apontou Elson da Silva, professor, mestre em Educação e liderança jovem de Ivaporunduva, há por parte dos educadores um despreparo, além da falta de conhecimento sobre a história do continente africano e dos negros no país, o que resulta na deficiência do ensino étnico-racial, dificultando a compreensão sobre as populações quilombolas no Brasil e no Vale do Ribeira.

Temos um passado que a escola nos negou, sempre fomos colocados como escravos e não como seremos humanos, sempre fomos vistos como negros capturados para trabalhar como escravos. Isso acontece ainda hoje. Nossos filhos ainda não conseguem se enxergar como sujeitos, sempre são colocados como marginalizados. A nossa história ficou escondida por muito tempo. É bonito falar de democracia, mas essa democracia não pode ficar só nas conversas. Quando estamos na escola, queremos aprender a somar e caminhar juntos com a escola formal. Esse conhecimento aplicado pela escola se não for olhado por toda a equipe gestora acaba destruindo todo o conhecimento construído na comunidade, com os ancestrais durante séculos. (DEFENSORIA PÚBLICA DO ESTADO DE SÃO PAULO, 2015).

Com a pesquisa de doutorado (NASCIMENTO, 2012) foi possível constatar que, se falta conhecimento por parte dos alunos sobre o seu lugar vivido, falta também para os professores, que em sua formação inicial não tiveram a oportunidade de estudar a história de ocupação do Vale do Ribeira 
e, portanto, conhecem pouco sobre as comunidades quilombolas, bem como sobre outras comunidades tradicionais presentes na região. Dessa forma, podemos dizer que tanto a garantia por formação inicial quanto continuada de professores para lidar com as especificidades culturais, históricas e ambientais do Vale do Ribeira visando à implementação de uma educação diferenciada, conforme a Resolução CEB/CNE nº 08/2012, parecem não estar sendo cumpridas.

Assim, o pouco conhecimento sobre o Vale do Ribeira por parte dos professores e gestores, a nosso ver, se constitui um obstáculo para identificar na história e na geografia da região conteúdos de ensino e aprendizagem potentes, impossibilitando o reconhecimento e a valorização das populações tradicionais presentes em seu território, como alerta o quilombola Oriel Rodrigues:

No Vale do Ribeira, a gente ainda tem um diálogo muito tímido. Tímido não somente com a questão dos quilombos. Tímido em relação ao Vale do Ri- beira e depois tímido em relação aos quilombos. A gente não conhece história do Vale do Ribeira. A história que passou no Vale do Ribeira, as pessoas conhecem muito pouco. Isso é uma coisa que cai ter que ser explorado. É uma outra coisa que também vai ter que ser explorado no campo da educação é que tem um público diferenciado que necessita de ter uma intervenção diferenciada. (NASCIMENTO, 2006, p. 77).

Todos os aspectos tratados neste tópico dialogam com as denúncias das lideranças relacionadas à falta de cursos de formação continuada para os professores, pois grande parte dos professores que atuam nesta escola vêm de outros municípios da região e não conhecem a realidade sociocultural daqueles alunos quilombolas. Ao serem questionados se os professores que dão aulas aos estudantes das comunidades conhecem e respeitam a história da luta quilombola ou possuem algum vínculo com a questão quilombola, somente seis lideranças disseram que sim, ao passo que 18 disseram que não, conforme podemos ver no Gráfico 3.

Gráfico 3 - Professor quilombola nas escolas e professores que conhecem e/ou respeitam a história da luta quilombola ou possui algum vínculo com a questão quilombola

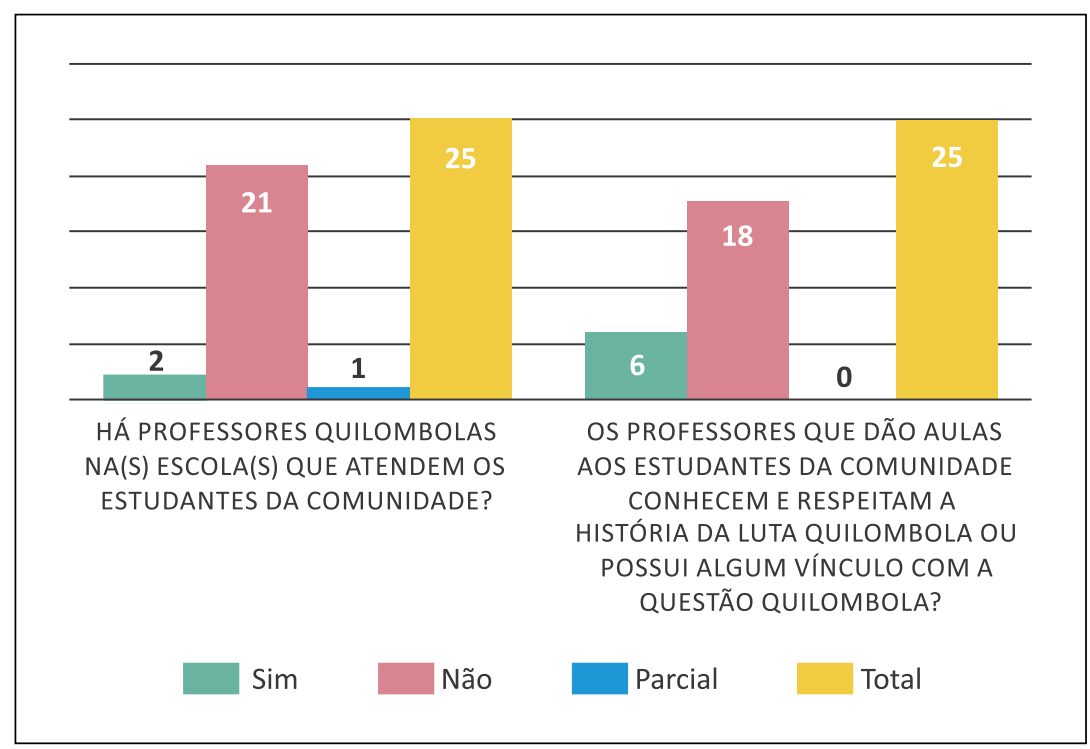

Fonte: Peres (2017, p. 20).

É importante ressaltar que esses professores, na maioria das vezes, assumem aulas nas escolas quilombolas ou naquelas que atendem alunos quilombolas em áreas rurais por falta de oportunidade nas escolas das áreas urbanas, devido à sua baixa pontuação, de acordo com o sistema ao qual são submetidos. Eles acabam lecionando por pouco tempo nestas escolas, geralmente durante um ou 
dois anos, o que não contribui para a construção de vínculos com as comunidades quilombolas atendidas pela escola e, portanto, para a construção de projetos pedagógicos envolvendo essas comunidades.

Ainda de acordo com o documento final da CONAE (2010, p. 131-132), a União, os Estados, o Distrito Federal e os Municípios deverão “[...] assegurar que a atividade docente nas escolas quilombolas seja exercida preferencialmente por professores/as oriundos/as das comunidades quilombolas". No entanto, ainda não se tem um quadro significativo no Vale do Ribeira de professores quilombolas para satisfazer a demanda tanto das escolas situadas em territórios quilombolas quanto das escolas que atendem alunos oriundos dessas comunidades. Por outro lado, há (poucos) professores quilombolas formados podendo lecionar nestas escolas, mas não há concursos públicos, conforme denúncia das lideranças quilombolas durante as audiências públicas. Os dados do Gráfico 3, acima, mostram que em apenas duas escolas há professores quilombolas lecionando.

Para a efetivação da modalidade de educação escolar quilombola é necessário, portanto, além dos cursos de formação continuada para os profissionais em serviço, a criação de programas de formação inicial de professores em Licenciatura e cursos de Magistérios que capacitem os futuros docentes, quilombolas e não quilombolas, para atuar em consonância com as Diretrizes Curriculares Nacionais para a Educação Escolar Quilombola na Educação Básica. Além disso, será necessário garantir aos docentes que atuam nesta modalidade condições dignas de trabalho, incluindo, entre outros aspectos, remuneração equilibrada às demandas para efetivação de uma educação de qualidade.

\section{Participação das comunidades na construção do Projeto Político Pedagógico e na gestão escolar}

Outros dois pontos fortemente levantados pelas lideranças quilombolas durante as audiências públicas se referem à participação das comunidades na elaboração do Projeto Político Pedagógico (PPP) e na gestão das escolas, pressupostos fundamentais para a implementação da educação escolar quilombola.
De acordo com as Diretrizes Curriculares Nacionais para a Educação Escolar Quilombola na Educação Básica:

[...] o ponto de partida para a conquista da autonomia pela instituição educacional tem por base a construção da identidade de cada escola, cuja manifestação se expressa no seu Projeto Pedagógico e no regimento escolar próprio, enquanto manifestação de seu ideal de educação e que permite uma nova e democrática ordenação pedagógica das relações escolares. O projeto político-pedagógico deve, pois, ser assumido pela comunidade educativa, ao mesmo tempo, como sua força indutora do processo participativo na instituição e como um dos instrumentos de conciliação das diferenças, de busca da construção de responsabilidade compartilhada por todos os membros integrantes da comunidade escolar, sujeitos históricos concretos, situados num cenário geopolítico preenchido por situações cotidianas desafiantes. (BRASIL, 2012).

O PPP deve ser entendido tanto como um processo quanto como um documento que evidencia o resultado das negociações dos diversos atores envolvidos com a escola (gestores, professores, técnicos, representação estudantil, família e comunidade local). Portanto, deverá abordar as especificidades históricas, sociais, culturais, econômicas e étnico-raciais da comunidade quilombola na qual a escola se insere ou é atendido por ela (BRASIL, 2012a).

A partir de diagnóstico sobre a realidade da comunidade quilombola e seu entorno e a posterior análise dos dados levantados, o PPP deverá considerar, de acordo com as Diretrizes Curriculares Nacionais para a Educação Escolar Quilombola na Educação Básica:

Os conhecimentos tradicionais, a oralidade, a ancestralidade, a estética, as formas de trabalho, as tecnologias, o patrimônio cultural e a história de cada comunidade quilombola;

As formas por meio das quais as comunidades quilombolas vivenciam os seus processos educativos cotidianos em articulação com os conhecimentos escolares e demais conhecimentos produzidos pela sociedade mais ampla.

A questão da territorialidade, associada ao etnodesenvolvimento e à sustentabilidade socioambiental e cultural das comunidades quilombolas deverá orientar todo o processo educativo definido no projeto político-pedagógico. (BRASIL, 2012b, p. 13). 
Segundo os depoimentos das lideranças nas audiências e os dados do questionário, na maioria das escolas os PPPs estão sendo elaborados sem a necessária articulação com as comunidades quilom- bolas. Entre as 25 comunidades que responderam ao questionário, somente três afirmaram terem participado da construção dos PPPs, conforme podemos verificar no Gráfico 4.

Gráfico 4 - Participação das lideranças das comunidades na gestão das escolas e das lideranças na construção do projeto pedagógico das escolas

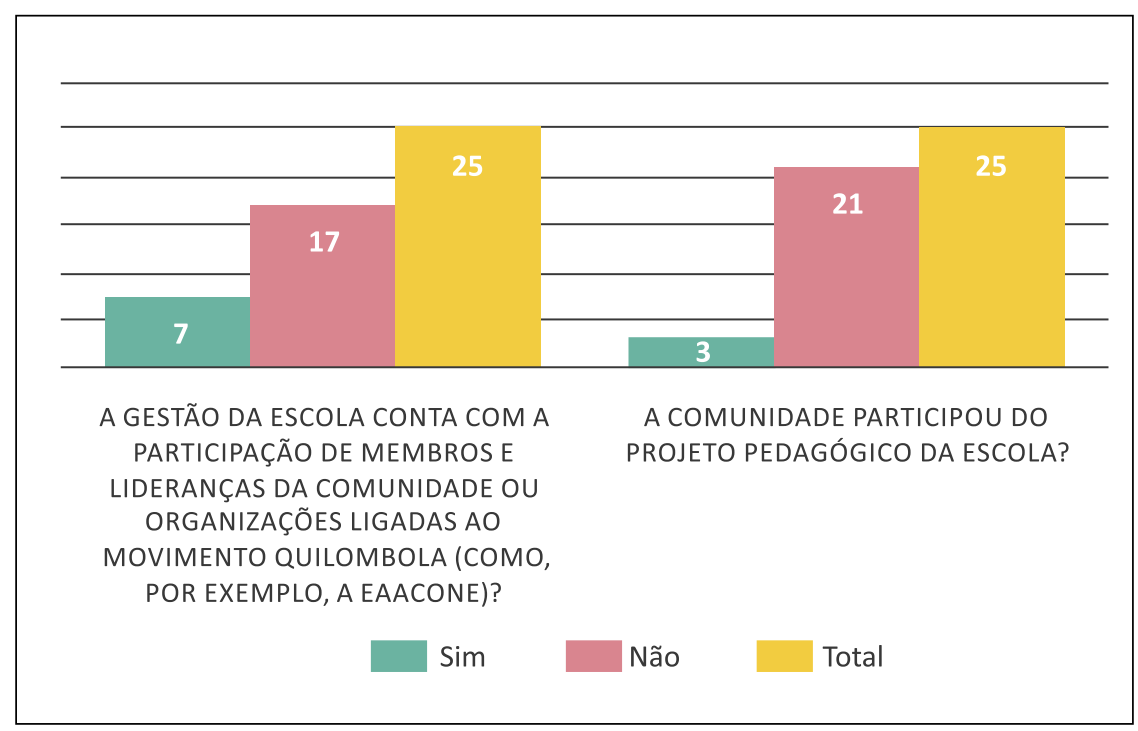

Fonte: Peres (2017, p. 18).

Em relação à participação das comunidades na gestão das escolas, a Resolução $\mathrm{CEB} / \mathrm{CNE} \mathrm{n}^{\circ}$ 08/2012 garante que:

As práticas de gestão da escola deverão ser realizadas junto com as comunidades quilombolas por ela atendidas. Nesse processo, faz-se imprescindível o diálogo entre a gestão da escola, a coordenação pedagógica, as comunidades quilombolas e suas lideranças em âmbitos nacional, estadual e local. A gestão deverá considerar os aspectos históricos, políticos, sociais, culturais e econômicos do universo sociocultural quilombola no qual está inserida. [...] Cabe enfatizar que a gestão das escolas quilombolas deverá ser realizada, preferencialmente, por quilombolas. Os sistemas de ensino, em regime de colaboração, poderão estabelecer convênios e parcerias com as instituições de Educação Superior e de Educação Profissional e Tecnológica, sobretudo com os Núcleos de Estudos Afro-Brasileiros e grupos correlatos dessas instituições, para a realização de processos de formação continuada e em serviço de gestores que atuam nas escolas quilombolas e nas escolas que atendem estudantes oriundos desses territórios. (BRASIL, 2012b, p. 49).
No entanto, os dados do Gráfico 4 nos mostram que apenas sete comunidades participam da gestão das escolas, enquanto 17 não têm participação. A articulação da escola com as comunidades quilombolas precisa ser entendida como um dos pilares da educação quilombola, portanto, faz-se necessário uma mudança de mentalidade da equipe gestora, reconhecendo a participação das comunidades não apenas como um direito em si, mas, sobretudo, como uma necessidade, permitindo identificar suas demandas, reconhecer seus conhecimentos e valorizar sua participação.

\section{Considerações finais}

Para além da constatação de lacunas na questão educacional no Vale do Ribeira, busca-se com estes apontamentos fomentar a reflexão sobre a necessidade de tradução urgente das conquistas legais representada pelas Diretrizes Curriculares Nacionais para a Educação Escolar Quilombola na Educação Básica em situações de ensino que se desenvolvam na sala de aula e promovam a cons- 
trução de aprendizagens significativas pelos alunos, contribuindo para o fortalecimento da identidade cultural quilombola.

É necessário um esforço coletivo e sistematizado entre a Secretaria da Educação do Estado de São Paulo, as diretorias de ensino, equipe de direção e coordenação da escola, equipe de professores e representantes quilombolas visando construir coletivamente o Projeto Político Pedagógico e o currículo escolar. É fundamental que os gestores e professores das escolas quilombolas e das escolas que atendem alunos quilombolas compreendam a importância desses dois instrumentos para a formação de alunos como sujeitos sociais conscientes do seu papel na sociedade, que não tenham vergonha de sua cultura, dos modos de produzir e das tradições do seu povo, ao mesmo tempo em que os prepare para viverem no mundo global, o que significa apropriar-se de conhecimentos diversos e não apenas daqueles relacionados ao seu grupo cultural.

Tanto a formação inicial quanto a formação continuada de professores em serviço são pilares estruturantes para a implementação da educação quilombola como modalidade de ensino, juntamente com a elaboração de material didático que atenda às demandas quilombolas. Para isso, urge mais esforços nas esferas municipal, estadual e federal.

Não temos dúvida de que somente a partir de ações coletivas e intencionais será possível construir um projeto de educação capaz de superar a visão eurocêntrica e homogeneizadora da diversidade cultural, que atenda aos princípios de uma educação para a igualdade racial e cumpra as diretrizes estabelecidas na Resolução CEB/CNE $n^{\circ}$ 08/2012 (BRASIL, 2012b).

\section{REFERÊNCIAS}

ALMEIDA, Alfredo Wagner. Os quilombos e as novas etnias. In: LEITÃO, Sergio (Org.). Direitos territoriais das comunidades negras rurais: aspectos jurídicos e antropológicos. São Paulo: Instituto Socioambiental, 1999.

BRASIL. Presidência da República. Casa Civil. Constituição da República Federativa do Brasil de 1988. Brasília, DF, 1988. Disponível em: <http://www.planalto.gov.br/ccivil_03/constituicao/constituicao.htm>. Acesso em: 02 mar. 2017.

. Ministério da Educação. Secretaria de Educação Fundamental. Parâmetros Curriculares Nacionais. Brasília, DF: MEC/SEF, 1997.

Presidência da República. Casa Civil. Decreto no 4.887, de 20 de novembro de 2003. Regulamenta o procedimento para identificação, reconhecimento, delimitação, demarcação e titulação das terras ocupadas por remanescentes das comunidades dos quilombos de que trata o art. 68 do Ato das Disposições Constitucionais Transitórias. Brasília, DF, 2003a. Disponível em: <http://www.planalto.gov.br/ccivil_03/decreto/2003/d4887.htm>. Acesso em: 02 mar. 2017.

Presidência da República. Casa Civil. Lei no 10.639, de 09 de janeiro de 2003. Altera a Lei no 9.394, de 20 de dezembro de 1996, que estabelece as diretrizes e bases da educação nacional, para incluir no currículo oficial da Rede de Ensino a obrigatoriedade da temática "História e Cultura Afro-Brasileira", e dá outras providências. Brasília, DF, 2003b. Disponível em: <http://www.planalto.gov.br/ccivil_03/leis/2003/L10.639.htm>. Acesso em: 05 mar. 2017.

. Presidência da República. Casa Civil. Decreto no 5.051, de 19 de abril de 2004. Promulga a Convenção no 169 da Organização Internacional do Trabalho-OIT sobre Povos Indígenas e Tribais. Brasília, DF, 2004. Disponível em: <http://www.planalto.gov.br/ccivil_03/_ato2004-2006/2004/decreto/d5051.htm>. Acesso em: 20 mar. 2017.

Presidência da República. Casa Civil. Decreto $\mathbf{n}^{0} \mathbf{6 . 0 4 0}$, de 7 de fevereiro de 2007. Institui a Política Nacional de Desenvolvimento Sustentável dos Povos e Comunidades Tradicionais. Brasília, DF, 2007. Disponível em: <http://www.planalto.gov.br/ccivil_03/_ato2007-2010/2007/Decreto/D6040.htm>. Acesso em: 15 mar. 2017.

Presidência da República. Casa Civil. Lei no 11.645, de 10 de março de 2008. Brasília, DF, 2008. Altera a Lei no 9.394, de 20 de dezembro de 1996, modificada pela Lei no 10.639, de 9 de janeiro de 2003, que estabelece as diretrizes e bases da educação nacional, para incluir no currículo oficial da rede de ensino a obrigatoriedade da temática "História e Cultura Afro-Brasileira e Indígena". Brasília, DF, 2008. Disponível em: <http://www.planalto. gov.br/ccivil_03/_ato2007-2010/2008/lei/111645.htm>. Acesso em: 05 mar. 2017. 
Ministério da Educação. Documento Final da Conferência Nacional de Educação - CONAE 2010. Brasília, DF, 2010. Disponível em: <http://conae.mec.gov.br/images/stories/pdf/pdf/documetos/documento_final_sl.pdf>. Acesso em: 05 mar. 2017.

. Ministério da Educação. Parecer CNE/CEB n 16, de 05 de junho de 2012. Descreve as Diretrizes Curriculares Nacionais para a Educação Escolar Quilombola na Educação Básica. Brasília, DF, 2012a. Disponível em: $<$ http://portal.mec.gov.br/index.php?option=com_docman\&view=download\&alias=11091-pceb016-12\&category_ slug=junho-2012-pdf\&Itemid=30192> . Acesso em: 05 mar. 2017.

Ministério da Educação. Resolução CNE/CEB no 08, de 20 de novembro de 2012. Define Diretrizes Curriculares Nacionais para a Educação Escolar Quilombola na Educação Básica. Brasília, DF, 2012b. Disponível em: <http://portal.mec.gov.br/index.php?option=com_docman\&view=download\&alias=11963-rceb008-12pdf\&category_slug=novembro-2012-pdf\&Itemid=30192>. Acesso em: 05 mar. 2017.

CALLAI, Helena C. O estudo do município ou a geografia nas séries iniciais. In: CASTROGIOVANI, Antônio Carlos. Et al (Org.). Geografia em sala de aula: práticas e reflexões. Porto Alegre: Editora da UFRGS, 2003. p. 77-82.

DEFENSORIA PÚBLICA DO ESTADO DE SÃO PAULO. Ciclo de Audiências Públicas sobre Educação Diferenciada no Vale do Ribeira. Registro, 2015.

Portaria no 01/2016 da PATC/DIR/DPVR/UR. Recomendação $n^{\circ}$ 03/2016, referente ao Procedimento Administrativo de Tutela Coletiva. São Paulo, 2016.

DIEGUES, Antônio Carlos. O mito moderno da natureza intocada. São Paulo: Hucitec, 2000.

FUNDAÇÃO CULTURAL PALMARES. Quilombos ainda existem no Brasil. Brasília, DF, 2008. Disponível em: <http://www.palmares.gov.br/?p=3041\&lang=en/>. Acesso em: 03 jul. 2017.

FUNDAÇÃO INSTITUTO DE TERRAS DO ESTADO DE SÃO PAULO (ITESP). Assistência a quilombos. São Paulo, 2015. Disponível em: <http://www.itesp.sp.gov.br/br/info/acoes/assitencia_quilombos.aspx >. Acesso em: 05 mar. 2017.

LUMNIOS, Giorgia. Comunidades quilombolas do Vale do Ribeira. São Paulo, 2017. Produzido sobre a Base cartográfica digital do IBGE 2015/2016 e da Agência Nacional de Águas (ANA). Imagem BING. Dados ITESP, 2015. Escala 1:2.000.000.

NASCIMENTO, Lisângela Kati do. O lugar do Lugar no ensino de Geografia: um estudo em escolas públicas do Vale do Ribeira-SP. 2012. 265 f. Tese (Doutorado em Geografia) - Departamento de Geografia da Faculdade de Filosofia, Letras e Ciências Humanas da Universidade de São Paulo (USP), São Paulo, 2012.

Identidade e territorialidade: os quilombos e a educação escolar no Vale do Ribeira. 2006. 159 f. Dissertação (Mestrado em Geografia) - Departamento de Geografia da Faculdade de Filosofia, Letras e Ciências Humanas da Universidade de São Paulo (USP), São Paulo, 2006.

O'DWYER, Eliane Cantarino (Org.). Quilombos: identidade étnica e territorialidade. Rio de Janeiro: Editora FGV, 2002.

PERES, Alice M. P. (Org.). Relatório da Situação da Educação nas Comunidades Quilombolas do Vale do Ribeira. São Carlos, SP: Universidade de São Carlos, 2017.

QUILOMBOS DO RIBEIRA. A luta pela terra. São Paulo, 2015. Disponível em: < http://www.quilombosdoribeira. org.br/luta>. Acesso em: 20 jul. 2015.

SANTOS, Milton. O espaço do cidadão. São Paulo: Nobel, 1998.

SÃO PAULO. Secretaria da Educação. Conselho Estadual de Educação Escolar Quilombola. Educação quilombola é tema de orientação técnica na rede estadual. São Paulo, 2013. Disponível em: < http://www.educacao.sp.gov. br/noticias/educacao-quilombola-e-tema-de-orientacao-tecnica-na-rede-estadual $>$. Acesso em: 05 mar. 2017.

STUCCHI, Deborah (Coord.). Laudo antropológico: comunidades negras de Ivaporunduva, São Pedro, Pedro Cubas, Sapatu, Nhuguara, André Lopes, Maria Rosa e Pilões. Documento de Trabalho. São Paulo: Ministério Público Federal, 1998. 